\title{
Utopia, distopia... Pandemia!
}

\section{Os sonhos de futuro e a temporalização das imaginações do porvir}

\author{
Utopia, dystopia... Pandemic!
}

\section{Future dreaming and temporalization of tomorrow's imagination}

\section{Cristina Teixeira}

Doutora em Linguística pela Universidade Estadual de Campinas e Professora Associado IV da Universidade Federal de Pernambuco. Universidade Federal de Pernambuco, Programa de Pós-Graduação em Comunicação, Recife (PE), Brasil.

\section{Mirella Pessoa}

Doutoranda pelo Programa de Pós-Graduação em Comunicação da UFPE e Mestre pelo Programa de Pós-Graduação em Comunicação da Universidade de Brasília. Universidade Federal de Pernambuco, Programa de Pós-Graduação em Comunicação, Recife (PE), Brasil.

\section{Introdução}

Com a pandemia do coronavírus assolando o mundo, o criador da série [Black Mirror], Charlie Brooker, acredita que não precisamos de mais distopias.

Revista Exame (2020)

Desde sua primeira temporada, Black Mirror ganhou o gosto dos assinantes da plataforma de streaming Netflix. Na série, o uso das tecnologias provoca simultaneamente encantamento e horror. A

\footnotetext{
${ }^{1}$ Disponível em: http://bit.ly/3ao2Mtj. Acesso em: 31 jan. 2021.
} 
maior parte dos episódios não especifica em que tempo histórico as narrativas ocorrem. Vislumbramos tratar-se do futuro; no entanto, as situações também nos remetem ao tempo do agora. Assim, os diretores da série nos fazem pensar sobre um presente que já se mostra distópico.

Black Mirror não está sozinha no rol de obras artísticas que fazem repercutir uma leva de debates acerca do cenário distópico da atualidade. Incontáveis são as produções contemporâneas que têm conquistado os holofotes e arrecadado altos montantes financeiros nos setores do cinema, da televisão, dos games e da literatura. Em território brasileiro, é inegável a força que as produções de caráter distópico ganharam nos últimos anos. Para ficar tão somente com exemplos do campo do audiovisual, podemos citar os filmes Branco sai, preto fica (2014), Divino Amor (2019) e Bacurau (2019), além das séries 3\% - Três por cento (2016 a 2020) e Onisciente (2020). Autores renomados de telenovelas também já anunciam seu interesse em desenvolver tramas distópicas. ${ }^{2}$ Não são apenas os criadores brasileiros que se mostram interessados em universos como esse; o público também manifesta sua curiosidade sobre a temática: nos últimos dez anos, a busca na internet pelo termo "distopia" disparou mais de dez vezes no Brasil, tendo seu pico em outubro de $2018 .^{3}$

Se, por um lado, a distopia ganha terreno, por outro, um suposto antônimo do termo, aquele que poderia de algum modo se contrapor ao imaginário catastrófico das distopias, quando surge, ganha ares distintos daqueles imaginados em outros tempos. Ou seja, não parece significar algo bom, positivo ou melhor. Hoje, quando a palavra "utopia" surge nas manchetes de jornais, nos comentários de economistas, nos debates políticos, parece evocar algo pejorativo. Por exemplo, um dos idealizadores da recémaprovada Reforma da Previdência receava que ela virasse algo "utópico". Em entrevista para o Jornal Estadão, ${ }^{4}$ o secretário da previdência Marcelo Caetano confessou temer que a proposta da reforma apresentada pelo governo fosse desfigurada, chegando a ser transformada em algo "inatingível". Em suas palavras, as reivindicações de mudanças dos parlamentares levariam a reforma a perder seu caráter pragmático e tornar-se algo idealizado, impossível de se alcançar.

Em 2019, a alcunha de utópico foi direcionada ao candidato à Prefeitura de São Paulo Guilherme Boulos. Em sua entrevista para o programa Roda Viva, no Canal Cultura, um dos entrevistadores disse que

\footnotetext{
2 Em maio de 2019, Glória Perez publicou no seu Twitter que seu próximo folhetim seria distópico. Disponível em: http://bit.ly/38rsIUK. Acesso em 10 mar. 2021.

${ }^{3}$ Disponível em: http://bit.ly/2KWh37B. Acesso em: 28 jan. 2021.

${ }^{4}$ Disponível em: http://bit.ly/3cj4Kxo. Acesso em: 26 jan. 2021.
} 
seu discurso era "muito bonito" e que parecia uma "aula de filosofia", mas tudo era "muito utópico", referindo-se às propostas de governo apresentadas pelo candidato. Guilherme Boulos, ao rebater as críticas a ele direcionadas, pareceu utilizar a mesma significação para o termo utópico, ainda que de forma irônica. Afirmou que a utopia apontada pelos entrevistadores estava na verdade na propaganda política de seu adversário, pois ela representava uma São Paulo que o candidato gostaria que fosse a cidade "real". ${ }^{5} \mathrm{E}$, quando o utópico está em um lado oposto daquele "pragmático", nem mesmo o atual ministro da economia Paulo Guedes, exaltado pelos grandes jornais nacionais por seu caráter "técnico", escapou da pecha carregada pela utopia contemporânea. Para Carla Araújo, ${ }^{6}$ colunista do site Uol, Guedes estaria sendo utópico ao esquecer os "trâmites necessários" para concretizar seu plano "otimista" de privatizações.

Esse breve diagnóstico parece demonstrar uma singularidade do nosso tempo: nossos sonhos de futuro articulam a ascensão da imaginação distópica e o enfraquecimento do pensamento utópico. Essa é a hipótese trabalhada neste ensaio para pensar as imaginações contemporâneas do senso de futuro atual.

Importante destacar que a oposição que fazemos aqui entre utopia e distopia é menos uma tentativa de encontrar uma definição única para os conceitos, e muito mais um esforço interessado de colocar em contraste duas formas diferentes de imaginar o futuro e procurar entender como o declínio de um (ou a transformação de seu sentido) e a ascensão e fortalecimento do outro poderiam estar relacionados com as novas formas de experiência com o tempo, com as dinâmicas de poder e com os regimes de verdade e de visibilidade nos quais uma imaginação distópica ganha força. Assim sendo, utopia e distopia não simplesmente se contrapõem, mas refletem a transformação das formas como a imaginação e como os saberes-poderes, a política, a literatura, o cinema passam a desenhar os projetos coletivos de sociedade.

Percebemos que, entre a ideia moderna e a contemporânea de utopia, há mudanças, e nos perguntamos: qual seria a mutação ocorrida entre a experiência moderna e a experiência contemporânea do tempo futuro? O que há de singular nesta experiência própria da atualidade? Tratar-se-ia da hipervisibilidade de um futuro de ameaças? De que modo a imaginação distópica do contemporâneo se

\footnotetext{
${ }^{5}$ Disponível em: https://bit.ly/3qXSXsw. Acesso em: 26 jan. 2021.

${ }^{6}$ Disponível em: http://bit.ly/2KYoift. Acesso em: 28 jan. 2021.
} 
entrelaça a uma experiência de presente que se estende sobre ele mesmo? Enfim, que imagens emergem diante de nós neste contexto?

É a partir do gesto genealógico (FOUCAULT, 1979, 1988) que procuramos elucidar as transições do regime moderno ao contemporâneo de imaginação do futuro que dá fruto a desejos próprios deste tempo em que vivemos. Partindo de algumas imagens ${ }^{7}$ do nosso tempo, tentamos buscar os pontos de transição, as rupturas e a inauguração de novos sentidos e anseios para o senso de futuro. Ao nosso ver, os exemplos acima mencionados, recolhidos do campo da política brasileira, - e os demais que serão apresentados ao longo deste ensaio - são índices dessas transformações.

Importante ressaltar que, quando falamos de futuro, não se trata do futuro propriamente dito. 0 futuro, como o tempo que ainda está por vir, sempre está adiante. Entretanto, é no presente que podemos, de certo modo, vivenciar esse tempo. As antecipações, os anseios, a imaginação, as projeções de futuro são, portanto, uma forma de experimentar no agora um tempo que ainda não chegou. É desse senso, é dessa experiência de tempo de futuro - dos modos, das técnicas, dos procedimentos, das imaginações que envolvem essa experiência - que tratamos (SANZ; PESSOA, 2020). Ademais, pressupomos que o regime contemporâneo de imagens e de visibilidade ${ }^{8}$ faz emergir nos circuitos hegemônicos de comunicação sentidos particulares de futuro imaginados - ora temidos, ora desejados - no nosso presente.

\section{Utopias modernas e futurísticas: do estático ao cinético na temporalização do não lugar}

"Mas a Utopia Moderna não deve ser estática, mas cinética, deve formar-se não como um estado permanente, mas como um estágio de esperança, levando a uma longa ascensão de estágios. [...] Essa é a

\footnotetext{
${ }^{7}$ A ideia que trazemos aqui de imagem possui uma perspectiva ampla. É pensada a partir da noção de "imagens dialéticas" de Walter Benjamin (2006) e do seu caráter de índice histórico. A imagem dialética tem o poder de explodir o continuum do tempo e romper com uma concepção linear da história, considerando cada fato uma imagem cristalizada no tempo. É inspiradas por todos os fragmentos da história recolhidos por Benjamin que pretendemos focar a análise das imagens naquilo que elas guardam de denúncia das dinâmicas do presente à qual são sincrônicas.

${ }^{8}$ Entendemos que as imagens que emergem entrelaçadas às tecnologias e aos meios de comunicação configuram verdades a respeito dos indivíduos e de suas experiências com o tempo do futuro, que se articulam em regimes de poder e visibilidade. Se cada formação histórica possui seu regime de verdade, seu conjunto de elementos que, enredado, produz as condições sobre as quais verdades são constituídas e cristalizadas em nossas percepções, nossos modos de ser e estar no mundo, também são as "regiões de visibilidade" e os "campos de legibilidade" - como propôs Deleuze (1988) - que fazem ver e falar, iluminar ou ocultar imagens proliferadas e enredadas a regras, técnicas e procedimentos, que colocam debates e assuntos em pauta, ou as silenciam.
} 
primeira e mais generalizada diferença entre uma Utopia baseada em concepções modernas e todas as Utopias que foram escritas na época anterior."

H.G. Wells, Uma Utopia Moderna (1905) ${ }^{9}$

A ideia de utopia está comumente associada à publicação homônima de Thomas More, a obra Utopia, de 1516. Desde então, não são poucos os estudos desenvolvidos em torno do conceito e seus desdobramentos políticos, filosóficos e, especialmente, literários. Petter Fitting (2009), em A Short History of Utopian Studies, indica três desdobramentos para a história da utopia: um referente àquele do gênero literário; um segundo, que aborda seu uso na linguagem; e um terceiro, sobre a reflexão teórica a respeito do conceito. Lyman Sargent (1994, p. 3), por sua vez, define o fenômeno do utopismo como "sonho social": ${ }^{10}$ os sonhos e pesadelos acerca dos quais os grupos sociais organizam suas vidas, que usualmente evocam uma sociedade radicalmente diferente daquela de que esses sonhadores fazem parte.

Para Russell Jacoby (2007) haveria uma distinção entre duas correntes do pensamento utópico: uma tradição projetista e outra iconoclasta. Segundo ele, os utopistas projetistas procuram mapear o futuro em seus mínimos detalhes (grupo no qual o autor inclui a própria Utopia de More e a de Edward Bellamy, Looking Backward). Já os iconoclastas sonham com uma sociedade superior, mas se recusam a apresentar medidas precisas para alcançá-la. Jacoby (2007) sugere que, atentos ao "perigo da iconografia sedutora" (p. 19), devemos inspirar-nos nos iconoclastas para recuperar o pensamento utópico sem incorrer no risco de vontade de dominação que certos detalhamentos das utopias projetistas carregam. É o que ocorre quando as utopias vociferam o que as pessoas devem comer, como devem vestir-se, que horas devem dormir. Os utopistas da corrente iconoclasta - pensadores como Adorno, Walter Benjamin, Herbert Marcuse e até mesmo Kafka, entre muitos outros de origem judaica - "foram utopistas iconoclastas sem mapas precisos" (p. 68). Longe dos detalhes visuais que mais tendem a confinar o futuro, eles procuram não o visualizar de modo preciso, mas manter os ouvidos atentos para escutá-lo. Neste grupo, estaria a obra clássica de Ernest Bloch (2005 [1959]) que trata do espirito utópico sem apresentar qualquer detalhe concreto sobre o futuro, mas invoca tal espírito através de reflexões sobre música, poesia e literatura.

\footnotetext{
${ }^{9}$ Essa e as demais publicações em inglês foram aqui reproduzidas em português a partir de tradução nossa.

${ }^{10}$ No original, "Social Dreaming".
} 
Para explorar uma revisão crítica dos paradigmas utópicos, Carlos Lima (2008) utiliza a metáfora das três grandes navegações. De acordo com o autor, em sua genealogia dialética da utopia, a primeira navegação corresponde à utopia filosófica, bem representada pelas obras de Platão ${ }^{11}$ e Aristóteles ${ }^{12}$. A segunda navegação diz respeito à constituição da utopia em sua forma literária. Esse paradigma surge com o declínio de um futuro orientado pelas previsões escatológicas da Igreja. As grandes navegações, os sonhos sobre a descoberta do mundo novo, a Reforma Protestante, a Revolução Copernicana da astronomia, a emergência de uma burguesia mercantil são o caldo político imaginativo desse novo paradigma. Na relação que traçaremos adiante, com a experiência do tempo do futuro, será possível perceber como a obra de Thomas More nasce nesse interstício, em que as previsões escatológicas da Igreja se enfraquecem, e os prognósticos, as navegações, o princípio dos estabelecimentos dos Estados começam a se delinear.

A utopia literária, embora ganhe corpo na linguagem, permanece abstrata, desmaterializada. Não se pode negar, entretanto, que um novo gênero literário é também uma máquina de produzir sentidos e de fornecer substratos para alteração da realidade. Germinam, assim, formas e modos de engajar as transformações que nos séculos seguintes se materializariam de outros modos. Como bem ressalta Vitor Ferreira Vieira (2015), vale destacar que tanto a utopia filosófica quanto a literária não pressupõem uma realização real e histórica dos ideais sobre os quais elas se apoiam. Trata-se de um exercício ora de reflexão filosófica, ora de criação artístico-literária sem uma perspectiva de aplicação histórica concreta.

Este cenário começa a mudar com a terceira navegação, aquela da utopia concreta, que coloca em evidência o sujeito histórico, o cidadão. Não o cidadão como substância abstrata, mas aquele de uma sociedade formada a partir de um contrato social determinado:

Esse termo, cidadão, emerge no século XVIII e se cristaliza no final desse mesmo século, na forma que distinguia o tratamento entre iguais na França, no tempo da Revolução. Logo, podemos definir o paradigma da utopia rousseauniana como a utopia do cidadão, este novo sujeito histórico que emerge nos setecentos e está presente em todo o lluminismo e, principalmente, na obra de Rousseau (LIMA, 2008, p. 87).

A utopia concreta de Rousseau, evocadora das ideias de contrato, igualdade, democracia e todo o campo do pensamento lluminista de sua época, tem como um de seus principais herdeiros o socialismo de

\footnotetext{
${ }^{11}$ A República de Platão é a primeira obra dedicada exclusivamente à reflexão sobre a cidade ideal.

${ }^{12} \mathrm{Na}$ sua obra Ética, Aristóteles apresenta uma teoria para a aristóbios [vida melhor]. Já em Política, ele oferece uma teoria para a aristopólis [cidade melhor].
} 
Marx. De acordo com Vitor Ferreira Vieira (2015), é em Marx que o paradigma utópico encontra o seu ápice de vinculação com a ação histórica concreta - e revolucionária.

Longe de tentar refazer esse abundante percurso dos estudos sobre a utopia, procuramos relacionar a sua emergência com uma certa experiência de tempo e entender como ela ganha novos contornos à medida que essa modalização temporal se modifica. Para tanto, um autor fundamental é Reinhart Koselleck (2006). Em seu livro Futuro Passado, ele analisa a transformação da modalização temporal a partir das categorias "horizonte de expectativa" e "espaço da experiência". Trata-se de duas categorias que entrelaçam passado e futuro a fim de entendermos o tempo histórico. A tese apresentada por Koselleck (2006, p. 314) é a de que, na modernidade, “a diferença entre experiência e expectativa aumenta progressivamente, ou melhor, só se pode conceber a modernidade como um tempo novo a partir do momento em que as expectativas passam a distanciar-se cada vez mais das experiências feitas até então". Para Koselleck, o futuro na modernidade ${ }^{13}$ se abre para a invenção dos sujeitos emancipados e agentes de seu tempo. E esse tempo, agora um fator agente de mudança e de transformação, deixaria para trás um futuro escatológico, cujas profecias administradas pela Igreja se renovavam indefinidamente. Uma modernidade que olha para um futuro possível de ser inventado e cujo passado deveria ser superado apresenta uma relação inédita com o horizonte de expectativa. Relação essa estabelecida também com as utopias modernas daquele tempo, além de estar intrinsecamente ligada à ideia de progresso e de aperfeiçoamento ascendente.

As utopias modernas são, segundo Koselleck (2014), diferentes daquelas cujo sistema de realidade se completa no espaço geográfico diferente, no outro lugar, como o caso das utopias marcadas pelo isolamento espacial e cuja descoberta estaria atrelada ao descobrimento desse novo mundo. A utopia temporalizada, por sua vez, estabelece seu sistema de realidade em outro tempo - mais precisamente no futuro - e demandaria seu caráter transformador, uma vez que, em lugar de ser o espaço perfeito (ou estático, como descreve H.G Wells na epígrafe deste tópico) e isolado, como a ilha de Utopia descoberta e descrita minuciosamente pelo marinheiro Rafael Hitlodeu, a utopia moderna e temporalizada estaria em processo de "aperfeiçoamento". Algo muito semelhante às utopias cinéticas de H.G. Wells (2009 [1905]), sobre as quais falaremos adiante.

\footnotetext{
${ }^{13}$ Trabalhamos aqui com uma periodização da modernidade que tem início em torno da segunda metade do século XVIII. Para Koselleck (2006), especificamente, as décadas entre 1750 e 1850 são marcadas por diversas transformações que caracterizariam a passagem para um tempo moderno, cuja experiência temporal também se altera.
} 


\section{ALCEU}

Modernidade, revolução e progresso estão estritamente entrelaçados com os projetos utópicos que emergem nesse período. Não apenas os projetos comunistas, muitos deles inspirados nas literaturas utópicas, mas também as ideias dos estados liberais cuja ascensão foi bem delineada por Foucault (2008) em Nascimento da Biopolítica. Não por acaso, os projetos civilizatórios centravam-se no governo das condutas dos cidadãos, orientados por um projeto de alcance futuro. O panóptico, por exemplo - modelo exemplar das técnicas de poder disciplinares próprio da modernidade -, assim como a organização em torno das instituições estatais, da educação nacional e dos planos de industrialização, encontra-se enredado a outros processos que atravessam a organização da sociedade capitalista, como a ascensão dos Estados-nação, o investimento do poder sobre as populações, a emergência do liberalismo. Esses processos se desenvolveram em paralelo aos projetos que imaginavam os estados socialistas. Nesse contexto, a figura do cidadão - também destacada por Lima (2008) na navegação sobre a utopia concreta que trabalha em prol de uma nação fortalecida é o sujeito protagonista de seu tempo. Não por acaso, a indústria e o trabalhador tornam-se figuras importantes do investimento do poder para o fortalecimento da nação, que deveria avançar em direção a um futuro de progresso.

É nesse cenário que Koselleck (2006) explicita a inauguração de um novo horizonte de expectativa. Se a modernidade, junto com as revoluções que ela guarda, anuncia uma nova forma de encarar o horizonte de expectativa, e o espaço da experiência não é mais aquilo que orienta o porvir, também os conceitos de revolução e de utopia encarnam novos sentidos nessa conjuntura. Assim, haveria uma modificação no caráter dos projetos utópicos, ou mesmo na emergência de projetos utópicos que precisamente se materializam em projetos políticos.

As utopias modernas tomam forma com tais características emancipadoras, imbricadas em uma dimensão temporal diferente das utopias anteriores. São as utopias futurísticas, aquelas que do tempo se alimentam - assim como as utopias cinéticas de Wells (2009 [1905]) - e que carregam a imaginação do lugar a ser alcançado, que já não podia mais ser encontrado pronto e finalizado no espaço terrestre nem no além. Para a utopia, então, "era preciso recuar para o futuro" (KOSELLECK, 2014, p. 124), em movimento e ação constante do homem.

H.G. Wells (2009 [1905]) aponta as principais diferenças entre a utopia propriamente moderna e aquelas que Ihe antecedem. Para o autor, obras como a República de Platão, a Nova Atlântida de Bacon e Notícias de Lugar Nenhum de William Morris falam de espaços territorialmente isolados, prontos, perfeitos 


\section{ALCEU}

ISSN: $2175-7402$

e finalizados. Já as utopias modernas - que, de acordo com Wells, deveriam ser cinéticas -, por outro lado, devem ser marcadas por seu movimento, "levando a uma longa ascensão de estágios" (p. 13). São utopias que consideram os homens portadores das inconstâncias, defeitos e incertezas que possuem hoje, e cujo trabalho de construção se daria a partir das "possibilidades do espaço e do tempo" (p. 15). Tal movimento e avanço seriam, para o autor, a garantia de que a sociedade seguiria em processo evolutivo contínuo.

Wells (2009 [1905]) entende que o manejo da evolução da espécie humana deve ser algo ativo e planejado pela própria humanidade, seja na administração da fecundidade da população, no cuidado com as crianças e no provimento pelo Estado de um ambiente que proporcione as condições de padrão mínimo de vida.${ }^{14}$ Tratar-se-ia, portanto, para Wells, de estabelecer na utopia moderna as condições para que não se permita que os sujeitos precisem sofrer ou batalhar por direitos básicos como alimentação, moradia ou vestimenta, questões sobre as quais "uma utopia planejada com base em linhas modernas certamente terá posto fim" (p. 156).

Enfim, entendemos aqui que as utopias modernas - temporalizadas, futurísticas (KOSELLECK, 2006) e cinéticas (WELLS, 2009 [1905]) - não apenas apontam para o futuro: elas precisam ser construídas e estar em processo constante de melhoramento em direção a esse novo lugar melhor. Uma nova relação com o tempo do futuro faz emergir assim outros projetos utópicos, agora atravessados por uma projeção de futuro que o vê como lugar não apenas a ser alcançado, mas construído, e cujo tempo aliado à ação do homem seriam fatores primordiais para alcançar a perfeição social. Tal utopia, aquela que "recua para o futuro" e avança em constantes estágios ascendentes, seria assim aquela que orientava um amanhã diferente do agora, vislumbrando no futuro o lugar melhor para a sociedade. O desenrolar do século, entretanto, com uma nova reorganização de forças, faz emergir outras possibilidades de imaginação que entram em disputa com aquela do amanhã melhor a ser construído pelo homem.

\section{Da antiutopia às distopias contemporâneas: um presente sem diferença e a ausência de coletivo}

"Teremos o março mais triste de nossas vidas", prevê pneumologista da Fiocruz.

\footnotetext{
${ }^{14}$ A máquina do tempo, de H.G. Wells, publicado em 1895, é, antes de A modern Utopia, uma especulação sobre aonde poderia chegar a civilização que não lidou ou gerenciou o processo evolutivo da humanidade (PARTINGTON, 2002).
} 


\section{ALCEU}

ISSN: 2175-7402

BBC News Brasil (2021) $)^{15}$

"Distanciamento social é uma utopia", diz senador governista crítico da OMS.

Notícias Uol $(2021)^{16}$

O ano de 2020 desenhou diante de nós um cenário muito próximo das produções distópicas: um vírus de alcance mundial, com alta capacidade de contágio, vem causando inúmeras mortes. Não há remédio, e a vacinação é lenta diante da aceleração do número de contaminados. Para remediar o problema, até o momento, só dispomos de ações preventivas que não incluem a vacinação (uso de máscaras, álcool gel, lavagem das mãos, isolamento social, quarentena, distanciamento social, lockdown). A conscientização e a ação individual não estancam o problema. Portanto, o futuro de todos e de qualquer um depende de ações coletivas que requerem a ação coordenada do Estado. No entanto, a intervenção estatal para evitar mortes paralisa a economia, pois implica vários tipos de confinamento e a diminuição da circulação de pessoas, especialmente nos centros comerciais lotados. Numa realidade econômica, política e social regida pela racionalidade neoliberal (DARDOT; LAVAL, 2016), a organização coletiva do isolamento social coordenada pelo Estado parece algo muito difícil de alcançar, soa "utópico", pois à racionalidade do mercado só interessa o próprio mercado, ou seja, é preciso manter a economia funcionando, mesmo que isso implique arriscar potencialmente vidas. Para grandes empresários brasileiros, o diagnóstico das ameaças da pandemia é bastante direto: "só os mais velhinhos morrerão", ${ }_{17}^{17}$ enquanto o mais alto cargo do Executivo admite que se trata de vidas que aparentemente já estavam próximas do seu destino final, e que, por isso, deveríamos deixá-las seguir seu caminho, e não "deixar a economia parar". ${ }^{18}$

Vale lembrar que, como expõem Dardot e Laval (2016), no neoliberalismo, a única função do Estado é garantir a manutenção da dinâmica concorrencial, operando a partir da liberdade individual dos sujeitos e do direito privado, fazendo prevalecer a ideia de maximização da liberdade por meio da demonização do social e da democracia popular. Para algumas correntes daqueles que defendem tal racionalidade, a ação do Estado em prol do bem comum, da igualdade ou justiça social estaria na continuidade do fascismo e do totalitarismo. A fala do presidente Jair Bolsonaro durante a pandemia da Covid-19 deixa entrever esse

\footnotetext{
${ }^{15}$ Disponível em: http://bbc.in/319ksNX. Acesso em: 7 mar. 2021.

${ }^{16}$ Disponível em: https://bit.ly/3bEHIQM. Acesso em: 7 mar. 2021.

17 Disponível em: http://bit.ly/3cs4F95. Acesso: 13 mar. 2021.

${ }^{18}$ Disponível em: http://glo.bo/38EtYE2. Acesso: 13 mar. 2021.
} 


\section{ALCEU}

ISSN: $2175-7402$

caráter supostamente autoritário de um Estado que age: "O povo tem que parar de deixar tudo nas costas do poder público. Aqui não é uma ditadura, é uma democracia". ${ }^{19}$

Não por acaso, também é a associação com o totalitarismo, com o fascismo e com o controle exacerbado da população que autores como Franco Berardi (2019) e Russel Jacoby (2007) atribuem para o princípio da desqualificação do pensamento utópico. De acordo com Berardi (2019, p. 68), "a realização das utopias do século XX teve geralmente a marca do totalitarismo e da violência". Segundo ele, as vanguardas, como o futurismo, o surrealismo e o dadaísmo foram movimentos que tiveram uma função importante na primeira parte do século XX e indicaram a "prefiguração de um outro futuro possível no horizonte histórico" (p. 67). Entretanto, a utopia, quando se realiza, toma "um signo contrário àquele com o qual ela se formou na vanguarda" (BERARDI, 2019, p. 67), e o fracasso dos projetos modernos faz emergirem novos ares para aquilo que estaria por vir. A história da tentativa de realização das utopias no século XX seria também uma pista para um espírito antiutópico apontado por Jacoby (2007). Além disso, o autor chama atenção para o equívoco da associação entre utopia e totalitarismo, manifesto no nacionalismo, no controle exacerbado das populações e dos corpos. Associação essa que se propaga em algumas correntes de pensadores desencantados pelo modo como projetos políticos da primeira metade do século XX tomaram forma, a exemplo do nazismo e do stalinismo.

“No final do século que tinha acreditado no futuro, a utopia perde força e surge uma percepção oposta do iminente, do inexorável, do inevitável, uma percepção distópica" (BERARDI, 2019, p. 68). Berardi (2019) indica o ano de 1977 como o ápice de uma transformação que vinha configurando-se ao longo das primeiras décadas do século XX. "O futuro se transforma em ameaça quando a imaginação coletiva se torna incapaz de ver possibilidades alternativas para a devastação, a miséria e a violência" (p. 135). Com o "sinal trocado", o futuro contemporâneo agora precisa ser evitado, e, nessas estratégias de evitá-lo, o tom alarmista das obras de distopia parece ressoar como uma sirene ativada a todo instante em um presente estendido.

Antiutopia e distopia parecem caminhar juntas para o enfraquecimento e a desqualificação do pensamento utópico, ao mesmo tempo que se fortalece, no contexto neoliberal, a percepção distópica apontada por Jacoby (2007) e Berardi (2019). A realização da distopia, em articulação com uma linha

19 Disponível em http://bit.ly/3voeGgc. Acesso em 13 mar. 2021. 
fortemente antiútopica, parece prender-nos ainda mais nesse círculo sem escape do capitalismo tardio, aquele ao qual, na ascensão do neoliberalismo, a primeira-ministra britânica Margareth Thatcher categoricamente afirmou não haver alternativa. Cunhando o conhecido slogan TINA (acrônimo para a expressão em inglês There's No Alternative), a primeira-ministra propaga mundialmente a certeza de que não haveria outra saída para a humanidade que não passasse por aquela submetida às leis do mercado, ao capitalismo, à globalização das políticas neoliberais:

A expansão das relações capitalistas, seja extensivamente, por uma outra rodada de acumulação por despossessão, seja colonizando novas esferas da vida, incluindo aquelas que haviam sido antes parcialmente desmercantilizadas pelas conquistas operárias, foi acompanhada por uma propaganda triunfalista que anunciava que a empresa privada e a democracia representativa parlamentar eram as formas finais de socialização humana enfim encontradas. Não havia nada melhor disponível e nunca haverá (MARQUES, 2020, p. 15).

Pensando na experiência particular de futuro atual, Helga Nowotny (1994, p. 51) explica que "a categoria temporal do futuro está sendo abolida e substituída por aquela do presente estendido". Além de não ser mais como era antes, o futuro atual encontra-se crescentemente obscurecido pelos problemas abertos no presente, e não mais oferece um espaço de projeção para nossos desejos e esperanças, aqueles que podiam ser projetados sem muita inibição. Isso porque ele [o futuro] parece remotamente suficiente para absorver tudo aquilo que não teve espaço, o que foi indesejado no presente. O futuro tornou-se realista até porque o horizonte de planejamento foi estendido, mas também porque isso significa que ele se desenha cada vez mais próximo do presente. Uma extensão do agora que se torna necessária para que possamos agir diante das catástrofes anunciadas. Diferentemente de uma experiência moderna, é o presente - e não mais o futuro - o novo tempo de ação, aquele sobre o qual devemos nos ocupar.

François Hartog (2013) também fala de uma expansão do presente no futuro vivido contemporaneamente a partir da reorganização dos regimes de historicidade. Se o século XX se iniciou com ares de futurismos, Hartog (2013, p. 140) afirma que ele "terminou mais presentista do que futurista". O próprio futurismo se faz presentismo quando traz para o presente um futuro que já é agora. A crise da fé no progresso orientador das utopias modernas, embalada pela descrença no futuro, pelo fim do estado de bem-estar social, por crises econômicas, como a de 1974, é também combustível para inflar um presente no qual são investidas todas as apostas de melhoria. Aliado a isso, Hartog destaca a importância do papel que desempenha o rápido desenvolvimento das exigências da sociedade de consumo e das inovações tecnológicas nesse sentimento contemporâneo de presente estendido. É na sobreposição dessas 


\section{ALCEU}

ISSN: $2175-7402$

exigências com uma experiência particular que coloca o presente como espaço de ação necessária que as imagens contemporâneas orientadas para o que se espera do futuro também se alteram. Se o futuro agora se encontra cada vez mais perto do presente sobre o qual devemos agir, outras imagens se delineiam apontando para o amanhã, ou para um hoje que não parece muito diferente do ontem, só que pior. Se parece não ser mais possível imaginar sociedades constituídas 800 mil anos adiante, como o fez H.G. Wells em sua Máquina do Tempo, que tipo de imaginação passa a permear nosso imaginário demandando ações urgentes no presente para que um futuro próximo seja evitado?

As previsões para os futuros cada vez mais próximos soam como a premonição da pneumologista da Fiocruz que anuncia um mês de março de 2021 ainda pior do que o que foi enfrentado, em uma conjuntura já muito catastrófica vivida no ano anterior. Se o futuro já não é mais sinônimo de mudança mas sim de agravamento do pior, uma vez que sua continuidade nos levaria ao futuro drástico -, algo aconteceu na nossa relação com ele. Com a virada de um ano pandêmico para 2021, muitos são os memes $^{20}$ - as imagens que rapidamente se replicam com conteúdo sucinto da circulação acelerada das redes - sobre a semelhança entre o março de 2020 e o março de 2021, que mais parece uma repetição agravada do mesmo. Espantados com a rápida passagem do ano, a sensação que nós brasileiros experimentamos, diante de um ano inteiro sem tomadas de medidas concretas e organizadas contra o vírus mortal, é a de que o futuro se coloca como uma extensão angustiante do presente acelerado que experimentamos isolados - física e politicamente - de qualquer possibilidade de coletividade. Como bem destaca Martins (2020, p. 16): “o deserto do fim da história é um eterno presente onde as coisas podem até se mover cada vez mais rápido, mas onde nada realmente muda". Esse parece também ser um campo muito fértil para as muitas produções distópicas que se multiplicam e ganham destaque, como apresentado no início deste ensaio.

Para Nowotny (1994), o futuro enquanto presente estendido é o espaço de reivindicação das gerações atuais. Assim como nas demandas por políticas que desacelerem os desastres ambientais, sociais e econômicos - tais como o da pandemia que vivenciamos no agora -, uma série de outras demandas se estabelecem na atualidade, em resposta a um futuro alarmante que bate à nossa porta. Para pensar com os cenários distópicos do audiovisual, os jovens suicidas da série Ad Vitam (Manuel Schapira e Thomas 
Cailley/2019) ${ }^{21}$ reivindicam que medidas sejam tomadas em uma sociedade onde o envelhecimento não mais se faz presente. Na série, o processo de regeneração, fruto dos avanços das tecnociências, tornou-se acessível a todos que o desejam. Entre outras demandas de uma sociedade que precisa agora administrar adultos que permanecerão indefinidamente jovens no mercado de trabalho, ironicamente, é disparada uma série de lutas pelo direito de morte. Em Filhos da esperança (Alfonso Cuarón/2006), de maneira oposta, o anseio da população reflete-se na vontade de recuperar a natalidade da humanidade tornada infértil em um cenário pouco otimista do planeta consumido pelo capitalismo destrutivo e devastador. Se ainda parece um pouco cedo para as produções inspiradas na pandemia do Covid-19 começarem a estrear nas telas do cinema, por outro lado, pensar sobre nossas aspirações nesse cenário soa cada vez mais urgente para que possamos encontrar formas de sair do presente sufocado da repetição piorada de um agora que não é suficiente para mitigar o medo do amanhã que bate à nossa porta.

\section{Breves conclusões: para escapar do presente eterno e do futuro asfixiado}

A utopia já não é mais como fora em tempos modernos, e a distopia se propaga em uma hiperabundância de imagens de um futuro de ameaças. Os sonhos do futuro e os desejos de porvir da sociedade parecem também testemunhar essa virada. O "futuro com sinal trocado" do nosso presente nos paralisa sozinhos na distopia atual, em que uma pandemia se expressa como a mais concreta experiência de um futuro que se deseja evitar, mas que, concomitantemente, parece muito distante de nos oferecer qualquer saída. Pensar as transformações das experiências temporais nos convida a suspender o tempo, a olhar de modo panorâmico para a forma como nos tornamos aquilo que somos e a tentar recolher nos fragmentos do presente aquilo que deixamos de ser. Da tentativa deste ensaio de refletir sobre os modos de imaginação do futuro e como eles se têm transformado em seus contextos históricos, espera-se que se possam abrir brechas, destravar imaginações, ou mesmo recuperar a Utopia como o horizonte, não aquela associada à violência e ao totalitarismo, que nos faz deixar de querer demandar o impossível. A Utopia como o horizonte que nos faz caminhar, essa sim, poderia resgatar-nos e ajudar-nos a respirar neste presente sem diferença que nos sufoca.

\footnotetext{
${ }^{21}$ Série disponível na plataforma de streaming Netflix.
} 
Cristina Teixeira

ORCID: https://orcid.org/0000-0002-3527-5501

Universidade Federal de Pernambuco, Programa de Pós-Graduação em Comunicação, Recife (PE), Brasil. Doutora em Linguística pela Universidade Estadual de Campinas E-mail: cristinateixeiravm@gmail.com

Mirella Pessoa

ORCID: https://orcid.org/0000-0002-7194-4186 Universidade Federal de Pernambuco, Programa de Pós-Graduação em Comunicação, Recife (PE), Brasil. Doutoranda e Mestre em Comunicação pela Universidade Federal de Pernambuco E-mail:mihpessoa@gmail.com

Recebido em: 15 de março de 2021.

Aprovado em: 16 de abril de 2021.

\section{Referências}

BENJAMIN, W. Passagens. São Paulo: Imprensa Oficial do Estado/ UFMG, 2006.

BERARDI, F. Depois do futuro. São Paulo: UBU Editora, 2019.

BLOCH, E. O princípio esperança. Rio de Janeiro: Contraponto EdUERJ, 2005.

DARDOT, P.; LAVAL, C. A nova razão do mundo: ensaio sobre a sociedade neoliberal. São Paulo: Boitempo, 2016.

DELEUZE, G. Foucault. São Paulo: Brasiliense, 1988.

FERREIRA, V. Vitor. Utopias e distopias no século XXI e pós-modernismo. Revista de Pós-graduação em Estudos de Linguagens - UFMS. Campo Grande - MS, Vol.19, no 38. 2015.

FITTING, P. A Short History of Utopian Studies. Science Fiction Studies, v. 36, n. 1, p. 121-131, 2009.

FOUCAULT, M. Nietzsche, a genealogia e a história. In: Microfísica do Poder. Rio de Janeiro: Graal, 1979.

FOUCAULT, M. História da sexualidade I: a vontade de saber. 13. ed. Rio de Janeiro: Graal, 1988. 
FOUCAULT, M. Nascimento da biopolítica. Curso no Collège de France: 1978-1979. São Paulo: Martins Fontes, 2008.

HARTOG, F. Regimes de historicidade: Presentismo e experiências do tempo. São Paulo: Autêntica, 2013.

JACOBY, R. Imagem imperfeita: pensamento utópico para uma época antiutópica. Rio de Janeiro: Civilização Brasileira, 2007.

KOSELLECK, R. Futuro Passado: contribuição semântica dos tempos históricos. Rio de Janeiro: PUC, 2006.

KOSELLECK, R. Estratos do tempo: estudos sobre a história. Rio de Janeiro: Contraponto Editora PUC Rio, 2014.

LIMA, C. Genealogia dialética da utopia. Rio de Janeiro: Contraponto, 2008.

MARQUES, V. O velho está morrendo e o novo sempre vem. In: O velho está morrendo e o novo não pode nascer. São P: Autonomia Literária, 2020. p. 7-31.

NOWOTNY, H. Time: the modern and postmodern experience. Cambridge: Polity Press, 1994.

PARTINGTON, J. S. The Time Machine and A Modern Utopia: The Static and Kinetic Utopias of the Early

H.G. Wells. Utopian Studies, v. 13, n. 1, p. 57-68, 2002.

SANZ, C. L.; PESSOA, M. Imagens do futuro: Risco e responsabilização na gerência neoliberal do amanhã. Tempo Social, v. 32, n. 2, p. 257-277, 2020.

SARGENT, L. T. The Three Faces of Utopianism Revisited. Utopian Studies, v. 5, n. 1, p. 1-37, 1994.

WELLS, H. G. A modern Utopia. Auckland: Floating Press, 2009.

\section{Filmografia}

AD VITAM. Direção: Thomas Cailley e Sébastien Mounier. Produção: Kilija / Arte. França: Netflix, 2018. Disponível em: https://www.netflix.com/title/81082327. Acesso em: 31/01/2021.

FILHOS da esperança. Direção: Alfonso Cuarón. Produção: Marc Abraham, Eric Newman, Hilary Shor, lain Smith, Tony Smith. Reino Unido: Universal Pictures, 2006. 


\section{Resumo}

Partindo de imagens dos sonhos de futuro do contemporâneo, recuamos historicamente para tentar mapear o enfraquecimento do pensamento utópico e a ascensão da imaginação distópica na atualidade. A partir do gesto genealógico, procuramos elucidar de que modo essa virada estaria relacionada com uma experiência temporal, que deu frutos a outras imagens de futuro na modernidade. Nesse sentido, utopia e distopia não simplesmente se contrapõem, são modos de imaginar o futuro estreitamente relacionados com dinâmicas de poder e modos de experienciar o tempo. O presentismo nos coloca isolados - física e politicamente - em um presente sufocado por previsões de futuro que se expandem num agora que parece se repetir. 0 presente torna-se o espaço de ação, embora a passagem do tempo não mais esteja associada ao alcance do lugar melhor ou à utopia moderna que irrompe no futuro para ser afeiçoada e concretizada no projeto coletivo imaginado para o amanhã.

Palavras-chave: Utopia. Distopia. Futuro. Imaginação. Presentismo. Temporalidade.

\section{Abstract}

Starting from images of contemporary future's dream, we have historically stepped back trying to map the weakening of utopian thought and rise of dystopian imagination in our present day. From genealogical gesture, we seek to elucidate how this turn would be related to a temporal experience, and how this relationship has been fructified other future images in another historical moment such as modernity. In this sense, utopia and dystopia are not simply opposed, here they are ways of imagining future closely related to power dynamics and ways of experiencing future time in nowadays. Presentism places us isolated - physically and politically - in a present suffocated by future's predictions that expands on today that seems to repeat itself. The present becomes the space for action, although time passage is no longer associated with reaching the best place or with modern utopia that breaks out in the future to be perfected and materialized in collective project imagined for tomorrow.

Keywords: Utopia. Dystopia. Future. Imagination. Presentism. Temporality 


\section{Resumen}

A partir de imágenes de los sueños del futuro contemporáneos, hemos retrocedido históricamente para tratar de trazar un mapa del debilitamiento del pensamiento utópico y el surgimiento de la imaginación distópica en la actualidad. Desde el gesto genealógico, buscamos dilucidar cómo este giro estaría relacionado con una experiencia temporal, que ha dado frutos a otras imágenes del futuro en la modernidad. En este sentido, la utopía y la distopía no se oponen simplemente, son formas de imaginar el futuro que están íntimamente relacionadas con las dinámicas del poder y las formas de vivir el tiempo. El presentismo nos sitúa aislados, física y políticamente, en un presente asfixiado por las predicciones del futuro que se expanden en un ahora que parece repetirse. El presente se convierte en el espacio de la acción, aunque el paso del tiempo ya no se asocia con llegar al mejor lugar o con la utopía moderna que estalla en el futuro para ser afectiva y concretarse en el proyecto colectivo imaginado para mañana.

Palabras clave: Utopía. Distopía. Futuro. Imaginacíon. Presentismo. Temporalidad.

Este artigo é publicado em acesso aberto (Open Access) sob a licença Creative Commons Attribution Non-Commercial (CC-BY-NC 4.0), que permite que outros remixem, adaptem e criem a partir do seu trabalho para fins não comerciais, e embora os novos trabalhos tenham de lhe atribuir o devido crédito e não possam ser usados para fins comerciais, os usuários não têm de licenciar esses trabalhos derivados sob os mesmos termos. 